\title{
AIRBORNE GAMMA-RAY SPECTROMETRIC AND MAGNETIC SIGNATURES OF FAZENDA NOVA REGION, EAST PORTION OF ARENÓPOLIS MAGMATIC ARC, GOIÁS
}

\author{
Lara Nigro Rodrigues Alves Ramos, Augusto César Bittencourt Pires \\ and Catarina Labouré Benfica Toledo
}

\begin{abstract}
Airborne geophysical data are an important tool for the interpretation of geological features. The variations observed in airborne magnetic and gamma-ray spectrometric data are typically used to differentiate geological units and delimit structures. In this context, this study aims to use gamma-ray spectrometric and magnetic airborne data to support the geological mapping in the Fazenda Nova region, located in the east portion of the Arenópolis Magmatic Arc. The processing of the gamma-ray spectrometric data consisted of generating $\mathrm{K}, \mathrm{U}, \mathrm{Th}$, total count, gamma-ray spectrometric ratios and ternary images. The anomalous magnetic field processing and enhancing generated the magnetic maps, which provided information about the structural framework of the area, while the gamma-ray profiles and images allowed the delineation of the geologic-geophysical domains. Fifteen domains were individualized, interpreted especially from ternary images, which displayed a good relation with the granite bodies mapped and indicated different rocks associated with the Goiás Alkaline Province, contributing to improving the geological knowledge of the area.
\end{abstract}

Keywords: airborne geophysics, gamma-ray spectrometric, Arenópolis Magmatic Arc.

RESUMO. Dados aerogeofísicos consistem em uma importante ferramenta para a interpretação de feições geológicas. Variações observadas em dados magnéticos e de espectrometria gama aéreos são usualmente utilizadas para a discriminação de unidades geológicas e delimitação de estruturas. Neste contexto, este estudo tem como objetivo o uso de imagens derivadas do processamento de dados magnéticos e gamaespectrométricos aéreos no suporte ao mapeamento geológico na região de Fazenda Nova, localizada na porção leste do Arco Magmático de Arenópolis. Para os dados gamaespectrométricos, o processamento consistiu na geração de imagens dos canais $\mathrm{K}, \mathrm{U}$, Th e Contagem Total, além das razões entre os canais e as imagens ternárias. 0 processamento e realce do campo magnético anômalo geraram as imagens magnéticas, as quais forneceram informações sobre 0 arcabouço estrutural da área, enquanto que imagens e perfis aeroradiométricos permitiram a delimitação dos domínios litogeofísicos. Foram individualizados 15 domínios, interpretados principalmente a partir das imagens ternárias, os quais apresentaram forte correlação com os corpos graníticos mapeados na região e delimitaram diferentes rochas associadas à Província Alcalina de Goiás, contribuindo para 0 aprimoramento do conhecimento geológico da região.

Palavras-chave: aerogeofísica, gamaespectrometria, Arco Magmático de Arenópolis. 


\section{INTRODUCTION}

Different data types are used to produce geological maps, such as field geology, geochemistry data and aerial photographs. The integration of geophysical and geological data helps visualizing better the geological and tectonic partitioning, identifying structures and lineaments and delineating rock types.

Currently, the availability of high-resolution airborne geophysical data and the ability to process and display large amounts of high quality geophysical data has increased the volume of geological information derived from geophysical images. The processing of these images results in defining the boundaries between geological units and visualizing magnetic structures with better resolution.

In the last decade, the state government of Goiás and federal agencies made available geophysical data covering much of the state and including various terrain types. Among the aerial surveys is the Arenópolis Magmatic Arc Project (Projeto Arco Magmático de Arenópolis, PAMA), which covered an area of $58,834 \mathrm{~km}^{2}$ with gamma-ray spectrometric and magnetic profiles in the southwestern portion of Goiás (Fig. 1).

The magnetic and gamma-ray spectrometric data of the PAMA in Fazenda Nova area, in the central-west region of Goiás, were corrected, processed, interpolated and micro-levelled to analyze the magnetic structures and the boundaries between the gammaray spectrometric domains. These data were integrated with the available geological data with the purpose of improving the geological knowledge of the region and supplying valuable information to studying the gold mines located in the area, thus boosting the mineral exploration in Goiás.

\section{GEOLOGICAL CONTEXT}

The study area is within the Tocantins Structural Province (Almeida et al., 1977); inside the geological domain of the Brasilia Fold Belt. It comprises terrains of the eastern portion of the Arenópolis Magmatic Arc and its south extension is partly covered by the Paraná Basin (Fig. 2).

The Goiás Magmatic Arc represents the juvenile crust with geochemical and isotopic signature of intra-oceanic magmatic arcs, with accretion that happened between 900 and $600 \mathrm{Ma}$ (Pimentel \& Fuck, 1992). It occupies the western part of the Brasilia Fold Belt and is exposed in two different portions, the northern portion known as the Mara Rosa Magmatic Arc; and the southern portion, the Arenópolis Magmatic Arc (Pimentel et al., 1999; 2000). These arches consist of volcano-sedimentary sequences that form NNE-NNW belts, separated by orthogneiss of tonalitic to granodioritic composition. The arch rocks are metamorphosed under greenschist to amphibolite facies, milonitized locally, but with some igneous textures and structures preserved (Robinson et al., 1999). The metaplutonic rocks represent the oldest magmatism arc in the region, with $\mathrm{Rb} / \mathrm{Sr}$ and $\mathrm{U} / \mathrm{Pb}$ ages between 0.93 and 0.86 , and their parental magma indicates primitive nature, with ${ }^{87} \mathrm{Sr} /{ }^{86} \mathrm{Sr}$ ratio varying between 0.7025 and 0.7042 (Pimentel \& Fuck, 1992; Pimentel et al., 1999). The meta-igneous and metasedimentary rocks were intruded by post-orogenic granites (ca. $600 \mathrm{Ma}$ ) associated with gabbro-dioritic bodies, which is a typical bimodal association.

The Arenópolis Magmatic Arc occurs in extensive areas in the southwest and southern portion of Goiás, at the Paraguay Belt boundary to the west and the Goiás Massif to the east. The supracrustal associations are characterized by volcanic rocks andesitic to dacitic and subordinate detritic sediments metamorphosed into greenschist facies. The orthogneisses are calcium to calcium-alkali, which comprise gray meta-granodiorites and meta-tonalites with biotite and hornblende (Pimentel \& Fuck, 1992, Rodrigues et al., 1999; Pimentel et al., 2000), crystallized into two main phases: ca. 950 and $800 \mathrm{Ma}$, of metaluminous nature, and between ca. 670 and $630 \mathrm{Ma}$, meta-peraluminous (Pimentel et al., 2000; 2004; Laux et al., 2004). The gneisses present mineral assemblages indicative of metamorphism in amphibolite facies and commonly exhibit preserved igneous textures and structures (Pimentel et al., 2000). The post-orogenic granites are metaluminous, characteristic of I-type and A-type intrusion (Pimentel \& Fuck, 1992, Pimentel et al., 2000).

In the study area, the outcropping lithologies are related to intra-oceanic island arc like orthogneiss, units of the Jaupaci Vulcano-Sedimentary Sequence and post-orogenic granites, and to young lithologies, represented by Cretaceous bodies of the Goiás alkaline province and Paleozoic sediments of the Paraná Basin, in addition to ample lateritic covers (Fig. 2).

The gneiss terrains predominate in the eastern portion of the area and consist of felsic plutonic rocks of granitic and granodioritic composition and small lenticular bodies of ultramafic rocks metamorphosed in amphibolite facies. The gneisses are composed by biotite and/or hornblende and present NNW-SSE trending banding and subvertical dips (Amaro, 1989). In the eastern portion of the area, the orthogneiss acquire mylonitic texture approaching the Fazenda Nova Shear Zone, with a significant increase of quartz and secondary muscovite, thus highlighting this zone in the flat topography of the gneiss terrain.

The Jaupaci Vulcano-Sedimentary Sequence consists of mafic metavolcanic and felsic rocks with apparently absent 


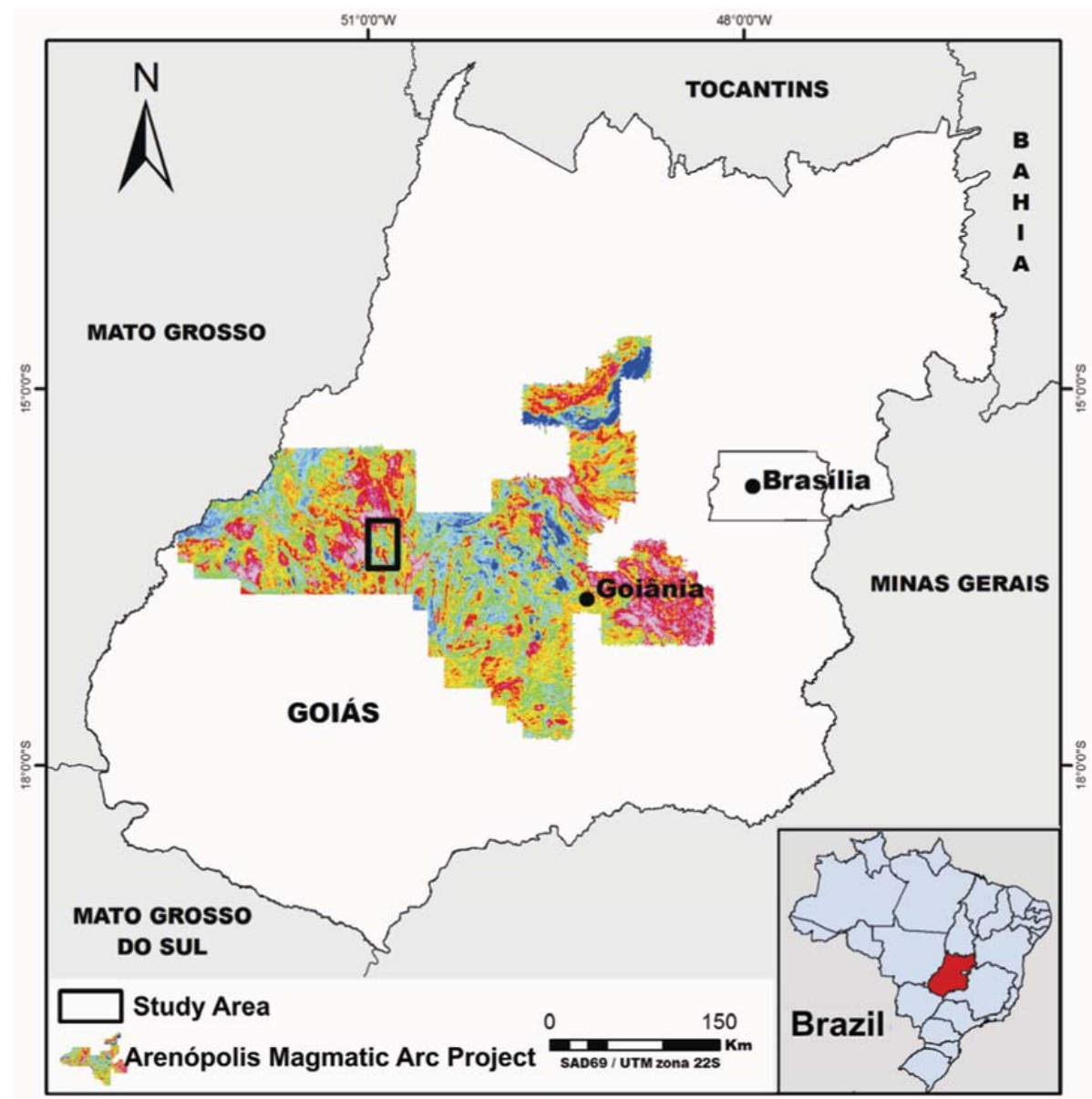

Figure 1 - Location of the first stage of the Airborne Geophysical Survey Program of Goiás, known as the Arenópolis Magmatic Arc Project, emphasizing the study area.

detritic metasediments (Amaro, 1989). The first are metabasalts with low-K tholeiites geochemical affinity, whereas the felsic metavolcanic rocks form the bulk of this sequence with predominant pyroclastic deposits of dacitic to rhyolitic composition of calcium-alkaline nature and intercalated metabasalts. The metavolcanic rocks are locally intercalated with metachert and intruded by small subvolcanic felsic bodies of granitic to granodioritic composition.

The syn to post-orogenic main granitic intrusions consist of the Iporá, Israelândia and Serra do Impertinente granites. The Israelândia Granite occupies the central portion of the area and is represented by biotite-hornblende granite and hornblende granite, with subordinate quartz-monzonite and granodiorite. The Iporá Granite occupies a small portion in the west part of the study area, consisting mainly of biotite granite, while the Serra do Impertinente Granite is located in the northern portion and has two main facies associated with distinct magmatic events. The porphyritic event is the oldest, and another equigranular magmatic event is later and more contemporary to the post-orogenic intrusions of the Neoproterozoic magmatism.

Cretaceous alkaline bodies representative of the alkaline province in southern Goiás (Lacerda Filho et al., 2000) occur in the central portion of the area. These intrusions comprise mainly dunites with peridotites, pyroxenites, serpentinites, gabbros, sienogabros, syenite nepheline, silexites, carbonatites, kimberlites and lamprophyres subordinate, distributed in an N30W elongated area (Junqueira-Brod et al., 2002; Moreira et al., 2008).

The significant N-S trending Moiporá-Novo Brasil shear system is located west of the study area, separating the Neoproterozoic geotectonic units of the Arenópolis Magmatic Arc of the Archean units of Goiás Massif (Mota Araújo et al., 2002). This system is represented by mylonites and ultra-mylonites with vertical foliation and horizontal stretch lineation (Rodrigues et al., 1999) and is responsible for generating subsidiaries zones such 

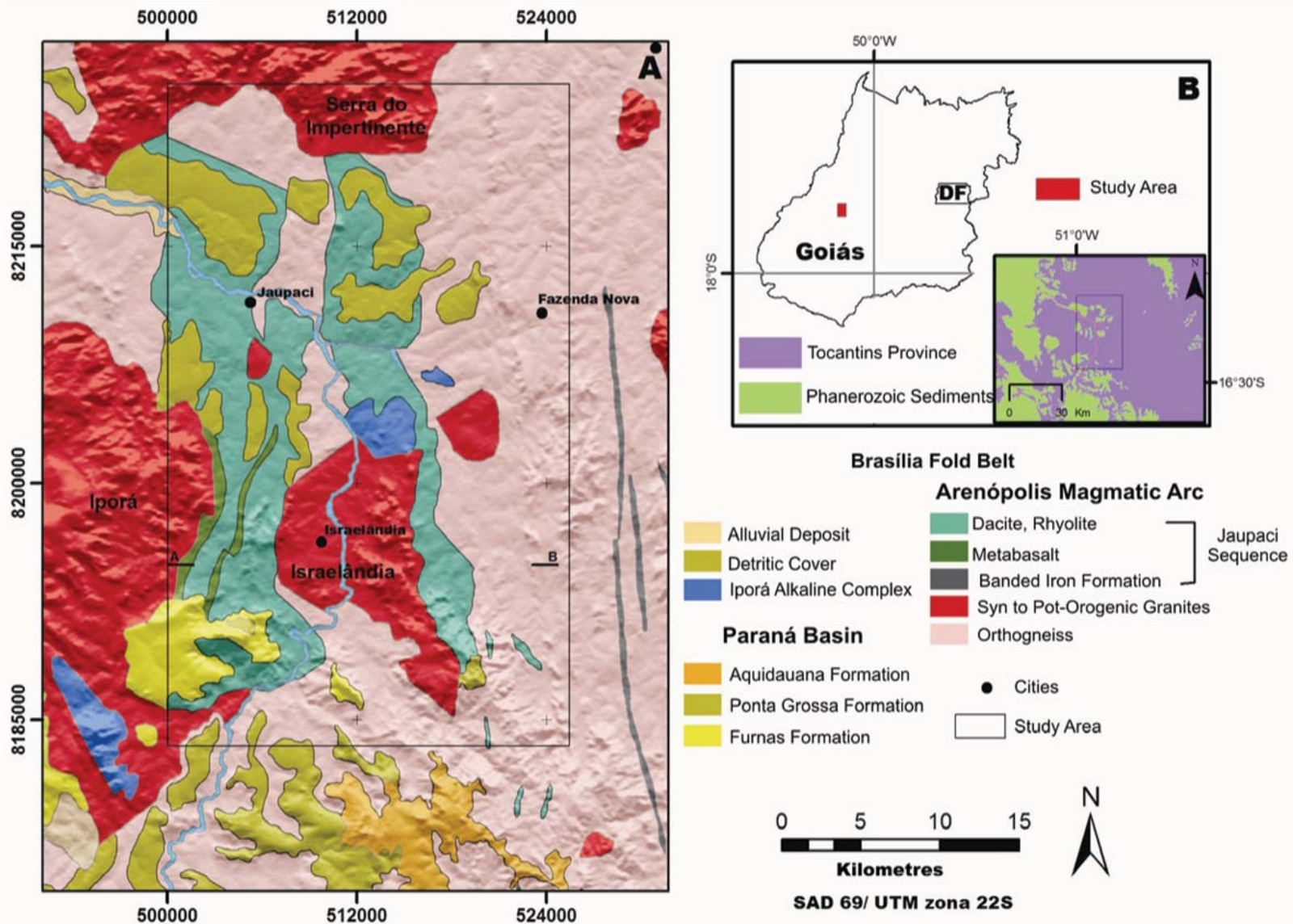

Figure 2 - Geological map overlaid on the digital terrain model of the SRTM (A) and study area (B). Source: Moreira et al., 2008.

as the N-S trending Fazenda Nova Shear Zone, in the eastern portion of the study area.

\section{MATERIALS AND METHODS}

\section{Airborne Geophysical Survey}

The aerial survey of the Arenópolis Magmatic Arc Project refers to the first stage of the Airborne Geophysical Survey Program of Goiás, conducted in 2004 by LASA Engenharia e Prospecções S/A. The project covered an area of $58,834 \mathrm{~km}^{2}$ and collected gamma-ray spectrometric and magnetic data along profiles, in which consecutive measurements were performed at intervals of $0.1 \mathrm{~s}$ in the magnetometer and $1.0 \mathrm{~s}$ in the gamma-ray spectrometer.

The N-S oriented flight lines were spaced $0.5 \mathrm{~km}$, and the control lines were $5.0 \mathrm{~km}$ apart and perpendicular to the flight lines (E-W). The nominal flying height was fixed at $100 \mathrm{~m}$ and controlled by the altimeter radar. The main features of the aerial survey are listed in Table 1.
Table 1 - Features of the Arenópolis Magmatic Arc Project.

\begin{tabular}{|c|c|}
\hline Overflown area $\left(\mathrm{km}^{2}\right)$ & 58.834 \\
\hline Sampling interval & $\begin{array}{c}80 \mathrm{~m} \text { (gamma-ray) } \\
8 \mathrm{~m} \text { (magnetic) }\end{array}$ \\
\hline $\begin{array}{c}\text { Flight space lines/ } \\
\text { Flight direction lines }\end{array}$ & $500 \mathrm{~m} / \mathrm{NS}$ \\
\hline $\begin{array}{c}\text { Tie space lines/ } \\
\text { Tie direction lines }\end{array}$ & $5000 \mathrm{~m} / \mathrm{EW}$ \\
\hline Flight altitude & $100 \mathrm{~m}$ \\
\hline Date of acquisition & $08-11 / 2014$ \\
\hline
\end{tabular}

Digital files of the airborne geophysical data were available in the database format of Geosoft'm (.gdb).

\section{Processing of airborne geophysical data}

Airborne geophysical data were performed using the Oasis montaj software, version 7.0, from Geosoft ${ }^{\mathrm{TM}}$. Initially, the spatial distribution of data and flight lines and the presence of outlier values were analyzed to determine whether they repre- 


\section{MAGNETOMETRY}

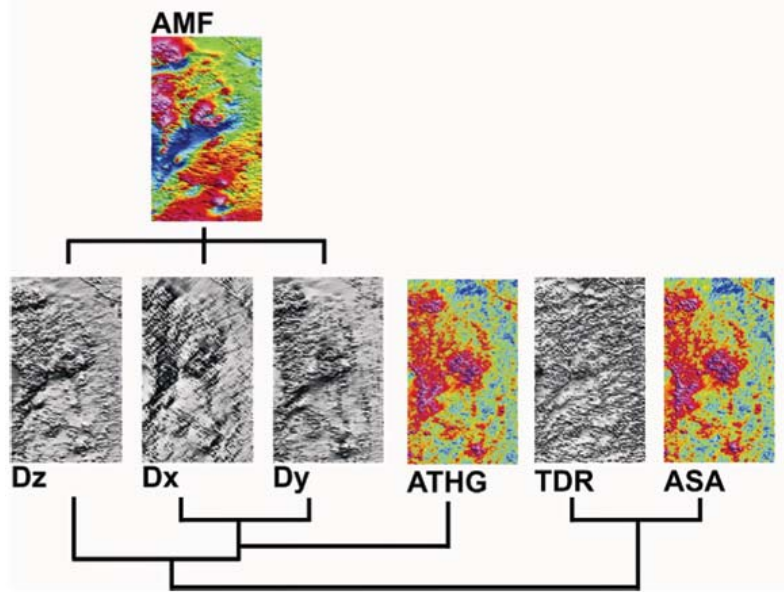

GAMMA SPECTROMETRY

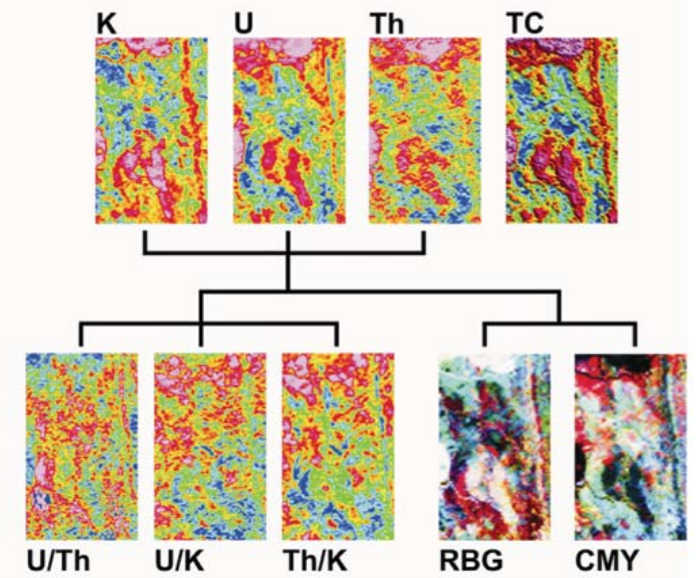

Figure 3 - Flowchart of the processing of magnetic and gamma-ray spectrometric data, where: AMF (Anomalous Magnetic Field), Dz (Vertical Derivative), Dx (Horizontal Derivative in X), Dy (Horizontal Derivative in Y), ATHG (Amplitude of Total Horizontal Gradient), TDR (Tilt Derivative), ASA (Analytic Signal Amplitude), $\mathbf{K}$ (Potassium), $\mathbf{U}$ (Uranium), Th (Thorium), TC (Total Count), U/Th (Uranium and Thorium Ratio), U/K (Uranium and Potassium Ratio), Th/K (Potassium and Thorium Ratio), RGB (RGB Ternary Image), CMY (CMY Ternary Image).

sented noise coming from poor calibration of instruments and preprocessing errors. The profiles displayed no outliers and, therefore, all the data were kept. The correction of the data was limited to removal of negative values from the gamma-ray spectrometric database. These values were found in greater number in the uranium channel, which has higher noise interference.

The images were prepared by interpolating the two-dimensional data on regular grids using the minimum curvature and bidirectional methods. The latter was applied to the magnetic data, since it is usually used in line sampled data due to the tendency to strengthen the trends perpendicular to the direction of the sampling lines. The minimum curvature method was applied to the gamma-ray spectrometric data due to fast and efficient processing and the fact that it is preferably used when there is no dominant trend perpendicular to the flight line (IAEA, 2003).

The 100-m unit cell used to manufacture the grids represents $1 / 5$ of the flight line spacing, as proposed by Vasconcelos et al. (1994) and Gunn (1998). These authors suggest unit cells with values between $1 / 4$ and $1 / 8$ of the nominal spacing of flight lines, and that magnetic data interpolations produce actual data if the unit cells do not exceed $25 \%$ of the flight line spacing; for the PAMA this distance is $125 \mathrm{~m}$ These values prevent information loss and noise incorporation, called aliasing (overlapping frequencies).

The usual levelling of airborne geophysical data does not eliminate all errors from the aerial survey. Thus, airborne geo- physical data may contain residual errors such as anomaly elongated along the flying lines, which may be removed by microlevelling (Luyendyk, 1997). The micro-levelling was carried out using the MicroLevel.gs algorithm developed by Blum (1999), based on the technique of Minty (1991).

After micro-levelling the data, magnetic and gamma-spectrometric images were created following the flowcharts of Figure 3 and enhanced by linear and non-linear filtering algorithms, being displayed as pseudo-colors or ternary images, using RGB and CMY composite techniques. The qualitative interpretation of the airborne geophysical images was made on a Geographic Information System (GIS) environment using the ArcView ${ }^{\text {TM }} 9.2$ software.

\section{Gammaspectrometry}

The gamma spectrometric method is based on detecting the gamma radiation emitted due to the nuclei stabilization process of radioactive elements. The gamma spectrometric data generated images related to the potassium (K), uranium (eU), thorium (eTh) and total count (TC) channels (Fig. 3). Ternary images in RGB and CMY pseudo-colors and the ratios between the $\mathrm{K}$, eU and eTh channels were also produced. The ratio between the channels is useful to visualizing the enrichment (or depletion) of one channel relative to another.

Radiometric images were integrated into the Digital Terrain Model (DTM), produced by altimetry data obtained during the 
aerial survey, in order to observe the distribution of radionuclides on the ground and the possible dispersions as pedogenic processes (Wilford et al., 1997).

\section{Magnetometry}

The Anomalous Magnetic Field (AMF) results from the concentration of magnetic minerals in rocks. It represents the magnetic field measured with the suppression of the magnetization coming from the interior of the Earth, estimated by the IGRF (International Geomagnetic Reference Field), and of the magnetization from solar storms and diurnal variation. From the AMF are generated images through linear filters that enhance the original information. These show the earth surface and subsurface information, which helps the structural interpretation of the area. This study presents the images of the Analytic Signal Amplitude (ASA), the Amplitude of the Total Horizontal Gradient (ATHG), the Tilt derivative (TDR), the horizontal derivatives (Dx and Dy) and the vertical derivative of the potential field (Dz).

The AMF presents dipole anomalies, while ASA provides the horizontal position of the anomaly source. The potential field derivatives represent the enhancement of high frequency magnetic signal. The vertical derivative is the variation of the anomalous magnetic field moving away vertically from the anomaly source (Blakely, 1996) and is useful in visualizing the contrast between the magnetic domains. The most used images to delineate the magnetometric domains were ASA and the first vertical derivative.

The Anomalous Magnetic Field of the study area has moderate magnetic relief and wide magnetic amplitude variation. The magnetic images were used to characterize the structural framework of the area. The main images used in visual interpretation of magnetic lineaments were the Tilt derivative (TDR) and the Analytic Signal Amplitude (ASA) (Fig. 3). The first enhances lineaments and magnetic foliation while ASA defines the position of the magnetic source, which contributes to the delineation of the various magnetic sources in accordance with the intensity of the magnetic field.

\section{RESULTS}

\section{Magnetic domains}

The magnetic images delineated three main magnetic fields associated with low, medium and high magnetic amplitudes (Fig. 4). The Magnetic domain A (DOM-A) displays high amplitudes and occurs in the central and western portion of the area. This domain is attributed to mafic volcanic rocks of the
Jaupaci Volcano-Sedimentary Sequence and intrusions of the alkaline province in southern Goiás. Low amplitudes are seen in the central north-northeast portion and are individualized in the DOM-B. This is characterized by low variation in the magnetic relief and has the lowest magnetic field gradients. The DOM-C has moderate magnetic relief and varied magnetic gradient, with a widely varied lithology. In this domain, there are small bodies of high magnetic amplitude, which do not exhibit preferred orientation and are associated with mafic volcanic bodies. The granitic intrusions of the area do not have high magnetic gradient and are associated with low variation of the magnetic relief.

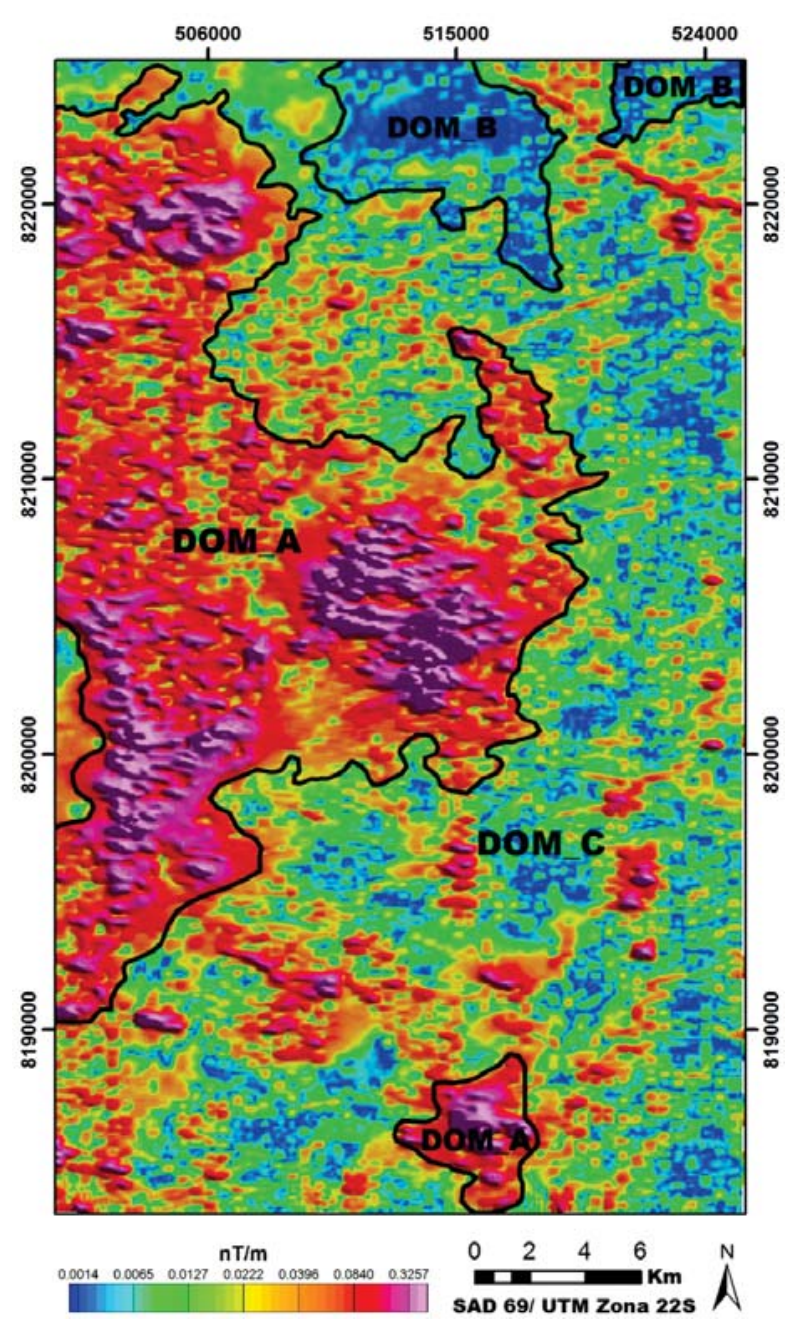

Figure 4 - The magnetic domains overlaid onto the Analytic Signal Amplitude image (ASA)

\section{Gamma-ray spectrometric domains}

The gamma-ray spectrometric domains were interpreted using all images of the radiometric channels, but especially, the result- 
ing images of the ternary compositions. These images defined 15 gamma-ray spectrometric domains with similar gamma radiometric signatures, classified according to the concentration of the radioelements $\mathrm{K}$, eU and eTh (Fig. 5). This classification was based on ternary false-color images, since they allow visualization of the relative contribution of each radioelement, unlike the total count (TC) images, whose gamma radiation window includes the contribution of the three elements without differentiating individual contributions.

Each radioelement was qualitatively classified into low, medium and high concentration, according to the contribution in the ternary images, defined by these images' color. The use of red, green and blue channels for $\mathrm{K}$, Th and $\mathrm{U}$, respectively, is the default for exhibiting gamma-ray spectrometric data (IAEA, 2003).

The domains related to granitic intrusions were well defined, while those representatives of supracrustal rocks showed no wellmarked boundaries, since greater variation occurs in the rock composition of these units. The study area features large lateriticdetritic covers, which were included in specific fields, as well as areas related with shear zones and along drainages, which modify the radiometric response of the units where they are inserted.

\section{Geological-geophysical interpretation Gamma spectrometric images}

Several factors contribute to the successful mapping of geologic units from airborne gammaspectrometry. Among these are strong contrast between the content of radioelements and little ground cover (Minty, 1997; IAEA, 2003). This last factor hampered the delimitation of the units located in the N-NE part of the study area, with extensive lateritic-detritic coverage (Fig. 6a). However, such coverage could be identified as they tend to preserve only the content of thorium and uranium, acquiring a cyan color in the RGB ternary image.

These alteration surfaces correspond to gamma-ray spectrometric domains from 10 to 13, which present distinct evolution of the laterization process, according to the degree of potassium and uranium depletion and consequent thorium enrichment. The lateritic-detritic covers occur mainly associated with the intermediate volcanic rocks of the Jaupaci Vulcano-Sedimentary Sequence, which displays distinct gamma spectrometric signatures, possibly due to the different compositions of volcanic rocks and different degree of laterization.

The study area presents significant lithological contrast for the delimitation of units from the gamma spectrometric images, with association of granitic, volcanic and sedimentary rocks. The total count image shows high radioactivity in the northern, western and center-southern portions of the study area, corresponding to syn- to post-orogenic granites of the Arenópolis Magmatic Arc. This image and the image related to the potassium channel also show high NS aligned radioactive value in the eastern part of the area, indicating the Fazenda Nova Shear Zone (Fig. 6b). This shear zone is formed by milonitized rocks composed of quartz and muscovite with subordinate feldspars (Figs. $6 \mathrm{c}$ and $6 \mathrm{~d}$ ). The large amount of muscovite present in this shear zone assigns positive anomalous values to the potassium channel image.

Figure 5 shows shear zones represented by the gamma spectrometric domain 2, with increased content of the three radioelements, but with greater potassium enrichment. In addition to the Fazenda Nova Shear Zone, a small shear zone was identified in the northwestern portion of the study area, in the volcanic unit domain, displayed in the RGB ternary and thorium channel images overlain to the digital terrain model (DTM) (Figs. 7 and 8). These areas represent topographic highs due to the abundance of quartz, which hampers weathering.

The image corresponding to the thorium channel superimposed on the MDT (Fig. 8) shows how relief influences the distribution of this element, which is the most immobile radioelement and the one that best illustrates the geological variation of a region.

The high contents of thorium in the central-northern portion of the study area, especially in areas adjacent to Serra do Impertinente Granite, near the Iporá Granite, and in the eastern part of the Israelândia Granite, represent lateritic plateaus. These plateaus are mostly associated with the weathering of volcanic rocks of the Jaupaci Sequence, and can also be visualized by superimposing the RGB image on the MDT, represented by the cyan and green, according to the dispersion of radionuclides $U$ and Th (Fig. 7).

The unit assigned to the alkaline province of southern Goiás in the geological map of the study area is represented by contrasting gamma spectrometric signatures, characterized by the gamma-ray spectrometric domains 5, 9, 11 and 13 (Fig. 9). The RGB ternary image displays high, medium and low radiometric signatures, which shows rocks of different compositions (Fig. 9). The identification of different lithotypes associated with the alkaline province was not performed in the field due to the scarcity of outcrops.

However, monzogranite with feldspar potassium phenocrysts was identified in the unit assigned to the alkaline province in southern Goiás inserted into the gamma-ray spectrometric domain 5 , which shows high radiometric potassium and low uranium and thorium levels. This granitoid displays perthitic 

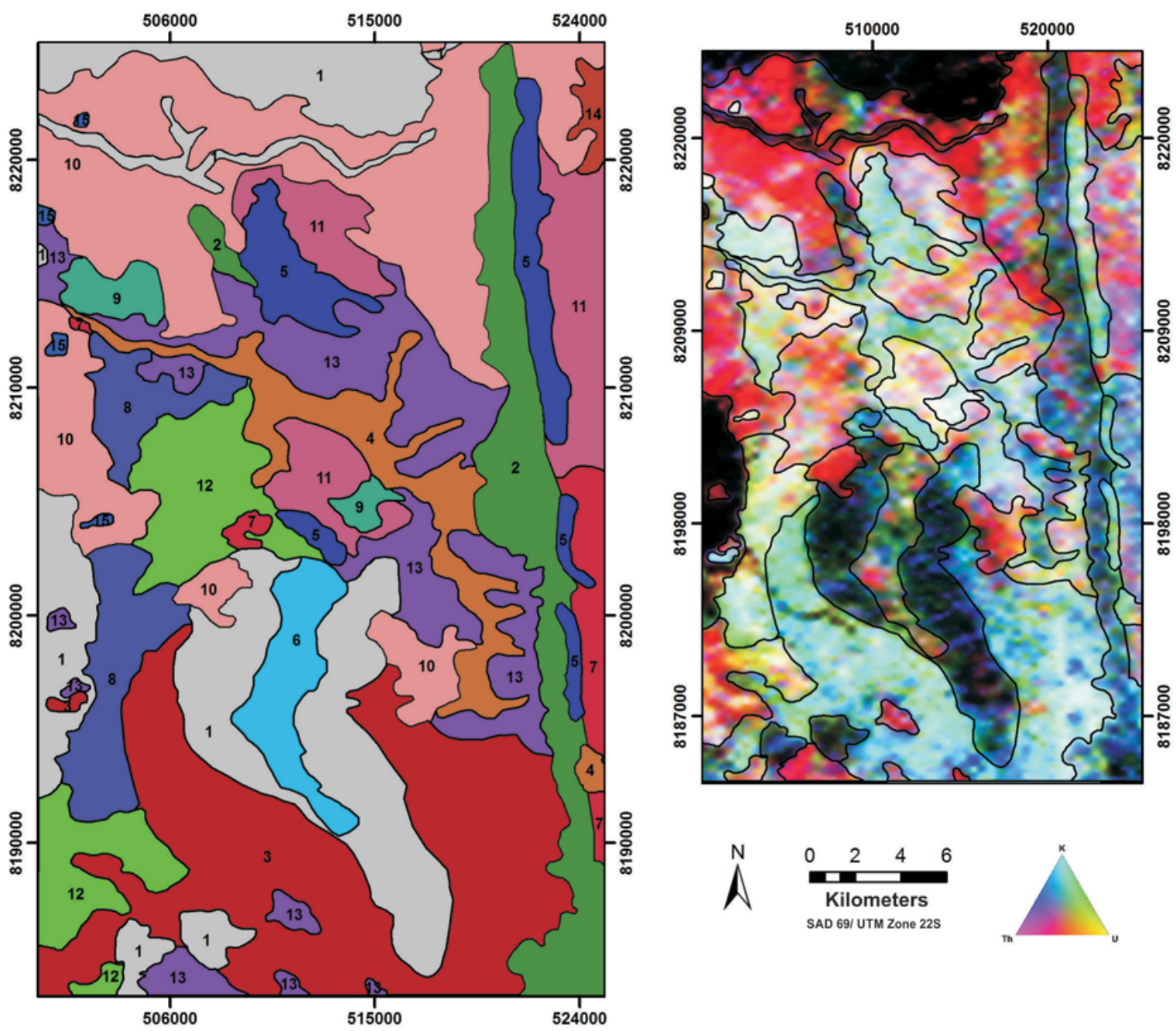

Gamma-Ray Domains

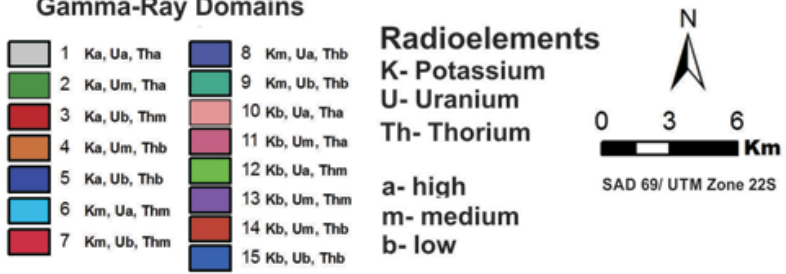

Figure $\mathbf{5}$ - Map of gamma-ray spectrometric domains (A) and the gamma-ray spectrometric domains overlapping the CMY ternary image (B).

texture and recrystallization of its borders, with plagioclase, hornblende, biotite and quartz associated (Fig. 10), and is represented by a NW trending body, red colored in the RGB ternary image on the northern edge of the Israelândia Granite (Fig. 9). This granite may constitute a xenolith in the Cretaceous rocks of the alkaline province or be associated with a potassium richer phase in Israelândia Granite, which would suggest an extension of this granite northwards and its association with a porphyritic magmatic phase. However, the ternary RGB image superimposed on the dig- ital terrain model shows that this potassium positive anomaly is located on the southwestern edge of the alkaline intrusion (Fig. 7). Thus, it could also represent the leaching of potassium and its consequent accumulation (Wilford et al., 1997).

Low radiometric values represented by a circular body on the northern edge of the alkaline province may refer to rocks bearing relevant mineral deposits (Fig. 9), such as carbonatites, which could be a prospective target for the discovery of niobium and phosphate deposits. 

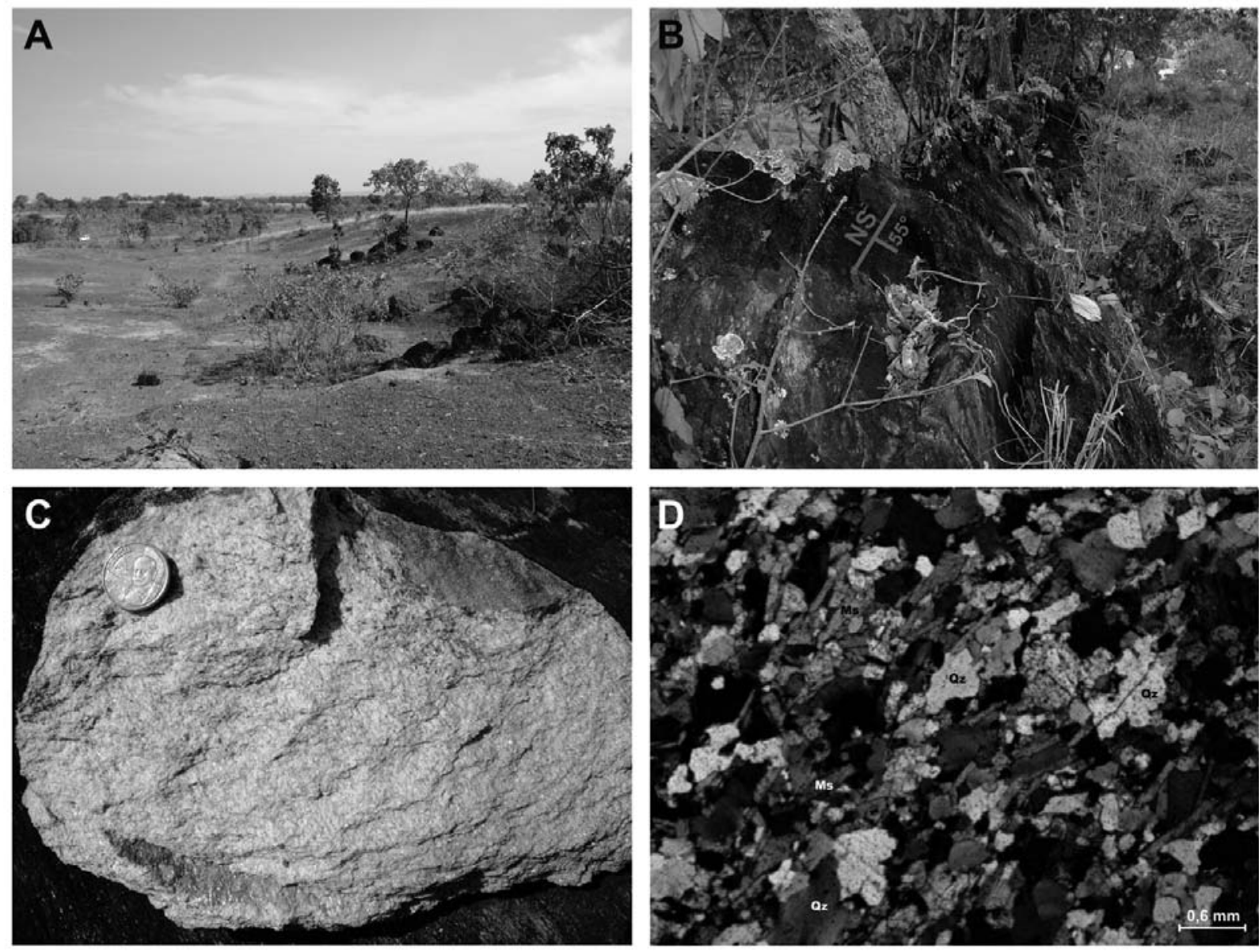

Figure 6 - Extensive detritic-lateritic cover (A), NS trending Fazenda Nova Shear Zone (B), macroscopic (C), and microscopic (D) samples of schist muscovite quartz (mylonite) of Fazenda Norte Shear Zone, where: Qz (quartz) and Ms (muscovite).

\section{Gamma-ray spectrometric profiles}

Figure 11 illustrates stacked gamma-ray spectrometry profiles of individual channels and the ratios between the channels, in addition to the geological profile, performed perpendicularly to the flight lines in the center of the study area. This profile (profile $A B$ ) is located on the southern portion of the study area and is displayed in the geological map of Figure 2. This integrated visualization of profiles facilitates the perception of gamma spectrometric responses with the mapped lithology, besides having the advantage of presenting the data in its full resolution compared to the grids, which are interpolated with a greater interval than the sampling interval (IAEA, 2003).

The profiles show a great contrast between the gamma spectrometric signature of the Iporá Granite rocks and the host rocks, represented by the metabasalts of the Jaupaci Sequence. These occur as two parallel NNE trending dikes in the southwestern part of the area and are well defined in the eTh/K ratio profile, represented by the negative peaks at 2.5 and 5.0 kilometers. In the western portion of the profile, the Iporá Granite limit seems to exceed the one proposed, since the high radiometric response of all individual channels is not compatible with the gamma spectrometric signature of the basic volcanic rocks, which have low radioactivity and consequent low gamma radiometric signature.

The three radioelements are present in high levels in the drains adjacent to the orogenic granites, while in other area drainages, positive potassium anomalies are observed with varying depletion of the $\mathrm{U}$ and Th contents, as seen in the CMY and RGB ternary images. Along the Rio Claro, the largest river in the region, various patterns of the content of radioelements were observed, with depletion of the three radioelements the most common. This fact is verified at the $10^{\text {th }} \mathrm{km}$ of the gamma spectrometry profiles, where the river runs in the NS direction in the center of the Israelândia granite and decreases the radiation 


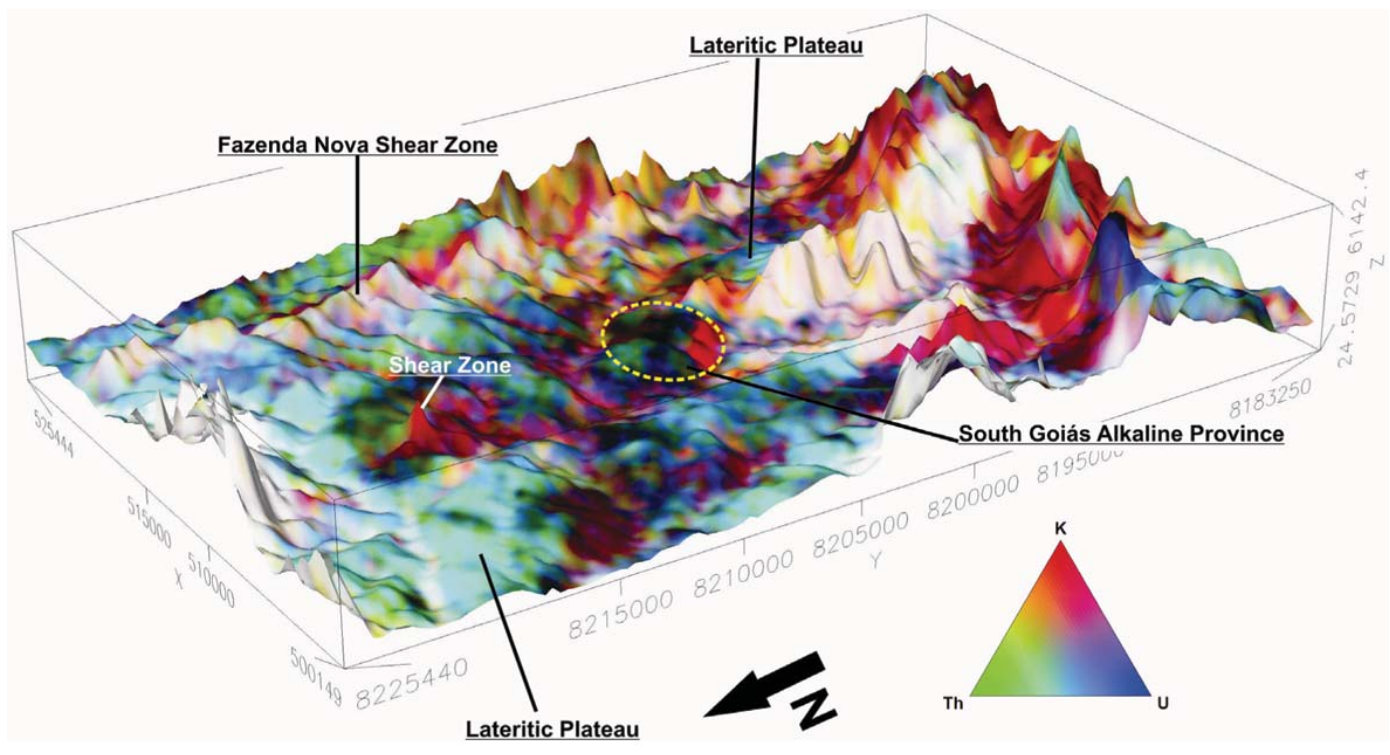

Figure 7 - RGB ternary image on the digital terrain model.

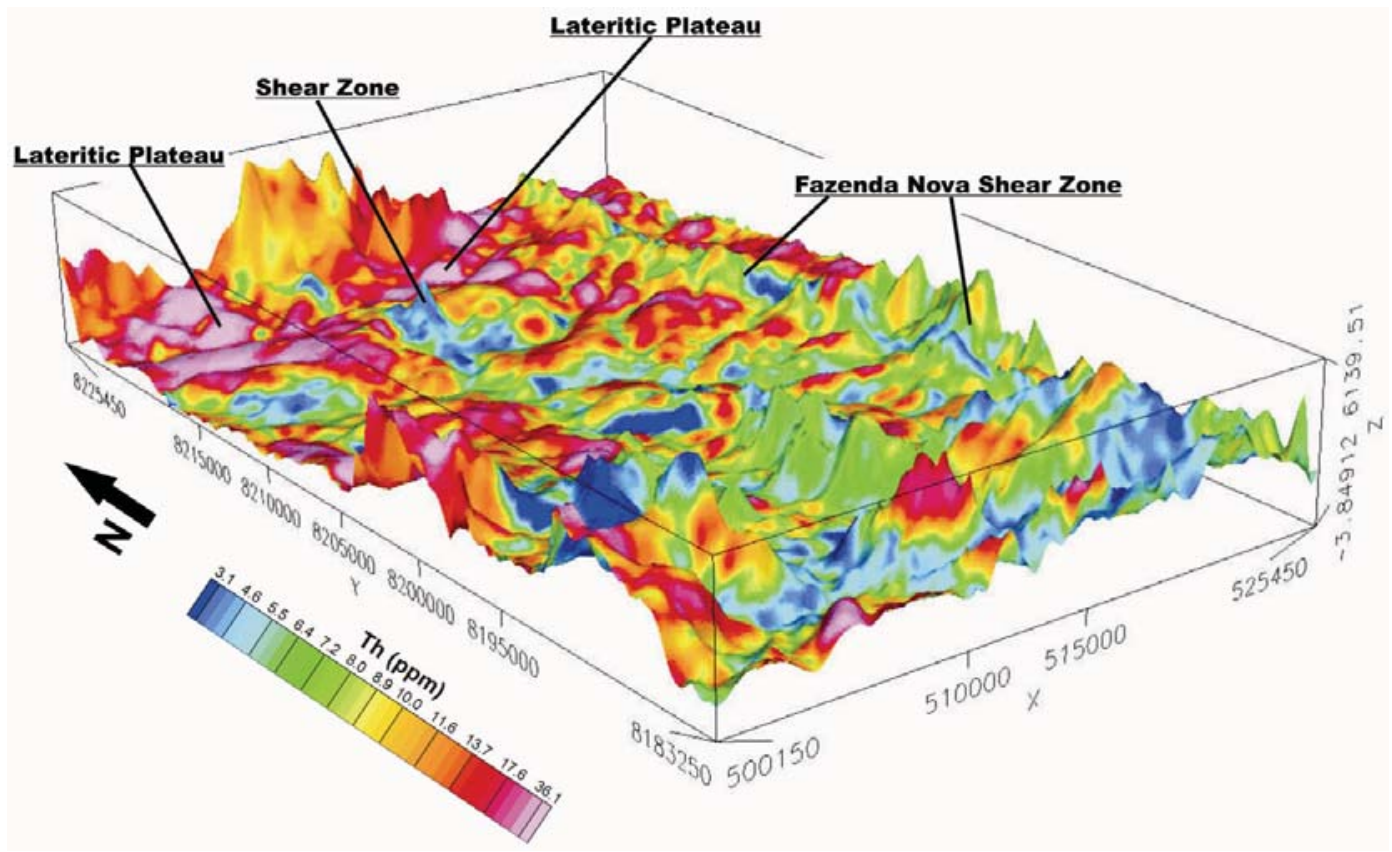

Figure 8 - Image of the Th channel on the digital terrain model.

response. Secondary drainages are seen at the $5^{\text {th }}, 9^{\text {th }}$ and $13^{\text {th }} \mathrm{km}$, and the ones running at the $9^{\text {th }}$ and $13^{\text {th }} \mathrm{km}$ are tributaries of the Rio Claro, which also show a decrease in the content of the three radioelements.

The radioelements values decrease greatly, especially potassium, at the eastern contact between the volcanic rocks of the Jaupaci Sequence and the orthogneiss of western Goiás. This fact occurs due to the presence of the detritic-lateritic plateau, which is well visualized on the ternary images. This plateau is followed by the Fazenda Nova Shear Zone, and extends approximately $2 \mathrm{~km}$ from the $20^{\text {th }} \mathrm{km}$ of the profile, conferring high potassium value and low to medium uranium and thorium values.

The Israelândia Granite has lower radioactive values than the Iporá Granite, as seen in the profiles of eTh and eU 


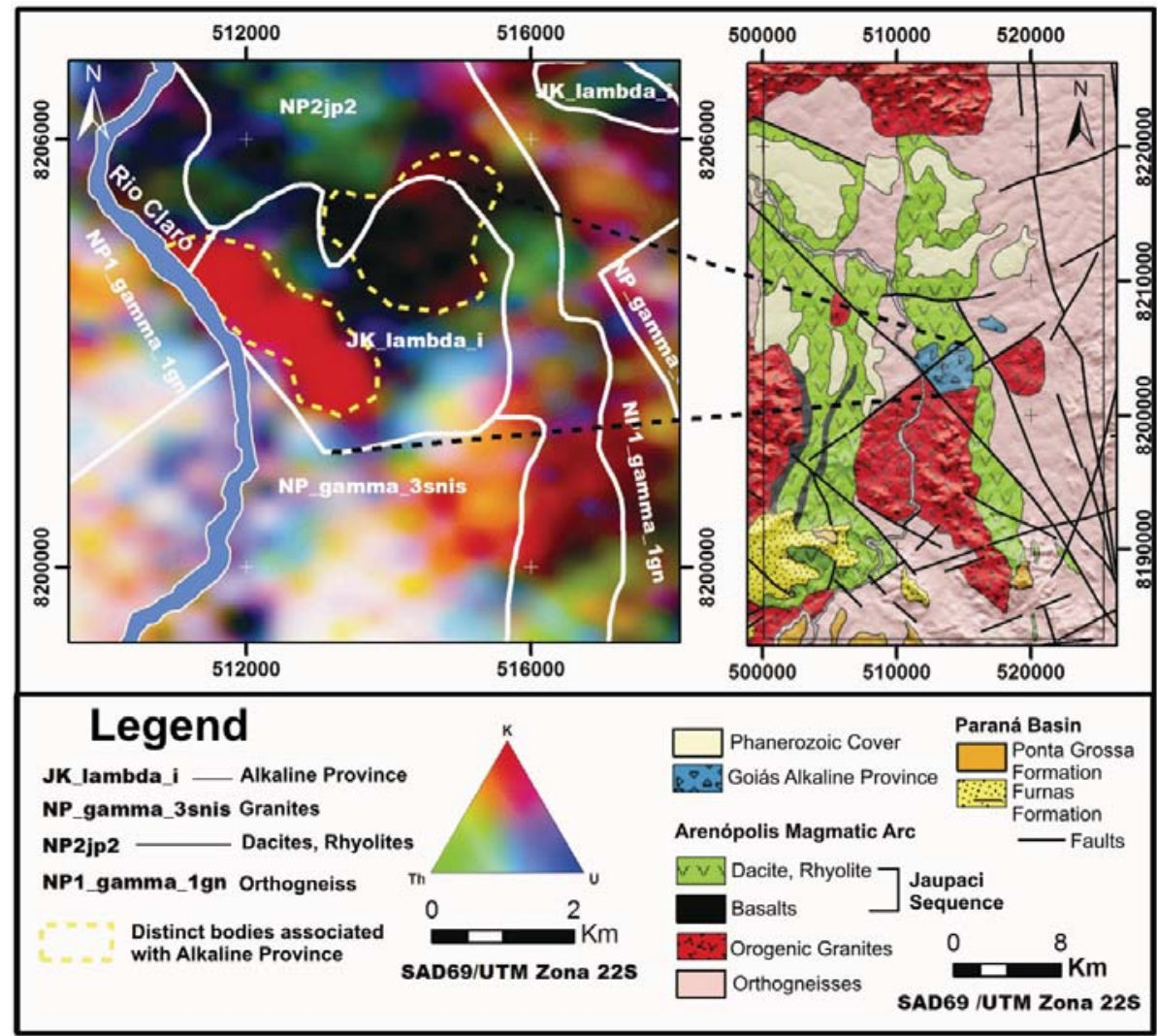

Figure 9 - Geological contacts superimposed on the RGB ternary image (K, Th, U) illustrating the different gamma spectrometric signatures of the alkaline province in southern Goiás.

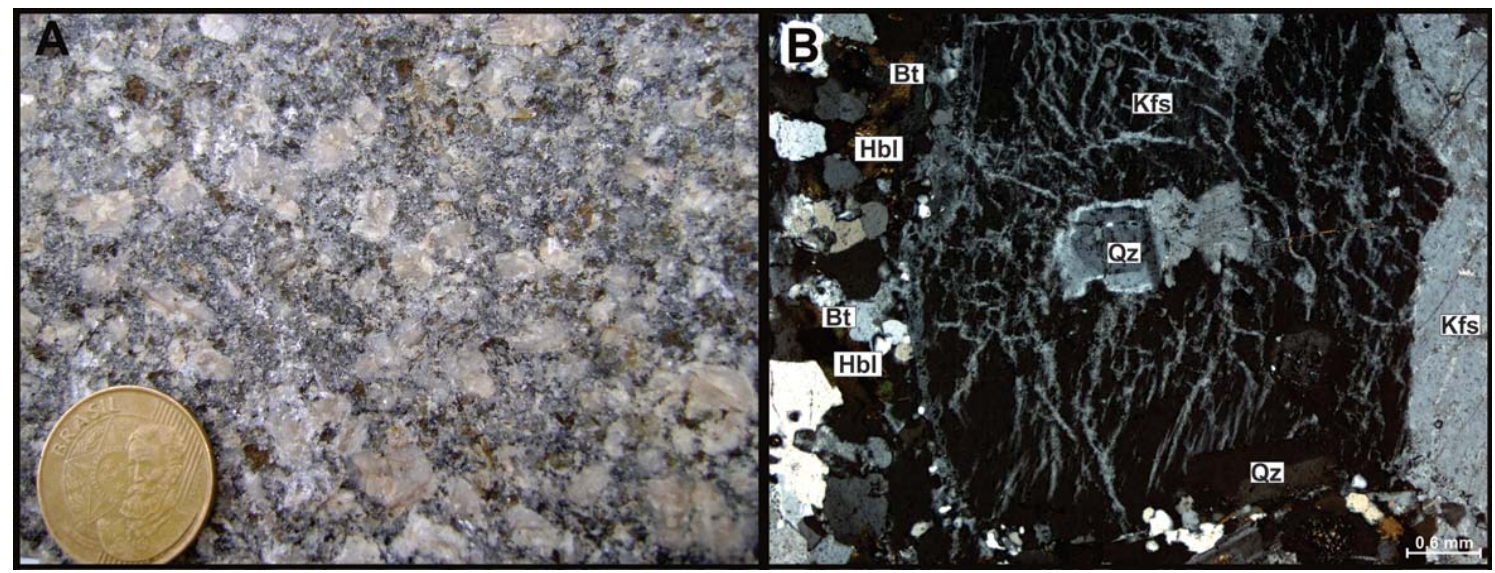

Figure 10 - Phenocrysts of potassium feldspar in macroscopic monzogranite sample (A) and phenocrysts of K-feldspar (Kfs) with perthitic texture, hornblende (Hbl), biotite (Bt), plagioclase (PI) and quartz (Qz) in hornblende-biotite monzogranite petrographic section (B).

channels. This is in agreement with petrological association of these granites, since Iporá Granite consists mainly of biotite granite with subordinate syenogranite and monzogranite, while the Israelândia Granite has granitic to quartz monzonitic composition with subordinate granodiorite and mafic to intermediate rock enclaves, which are interpreted as hybrid rocks resulting from the magma mixing (Pimentel \& Fuck, 1987; Amaro, 1989). 

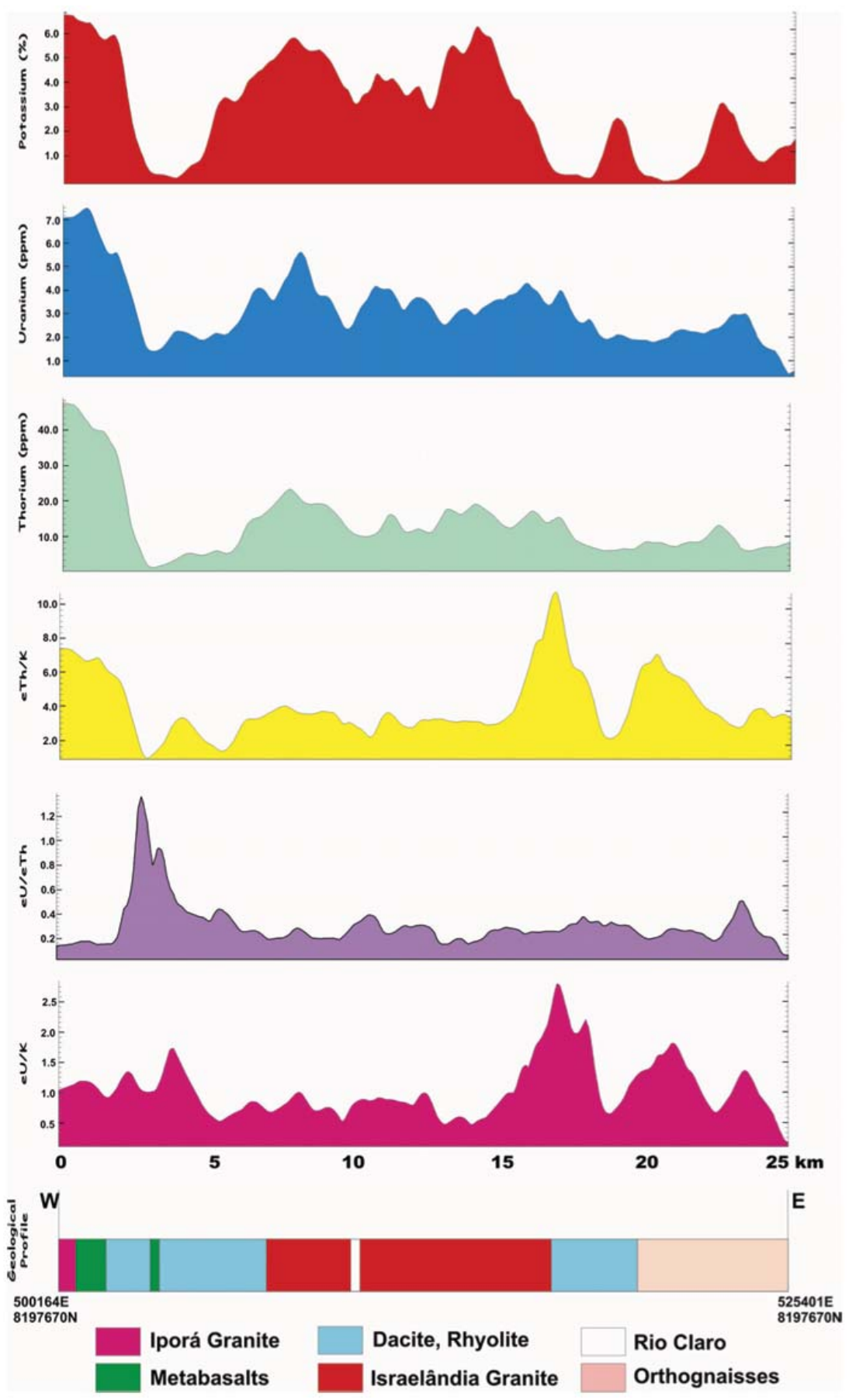

Figure 11 - Stacked gamma-ray spectrometric profiles illustrating the K, eU and eTh channels; gamma spectrometric ratios eTh/K, eU/Th and eU/K; and the geological profile AB (see geological map of Fig. 2).

\section{Structural features}

The major gamma spectrometric structural features were interpreted from the total count image, with illuminations between 45 and $315^{\circ}$. The analysis of this structure shows the predominance of NW-SE lineaments with subordinate NS and NE-SW lin- eaments (Fig. 12). The structures interpreted through gammaray spectroscopy are shallower than those interpreted from the magnetic data and are associated with contrasting values of the measured radioelements, which may represent areas of structural weakness. 


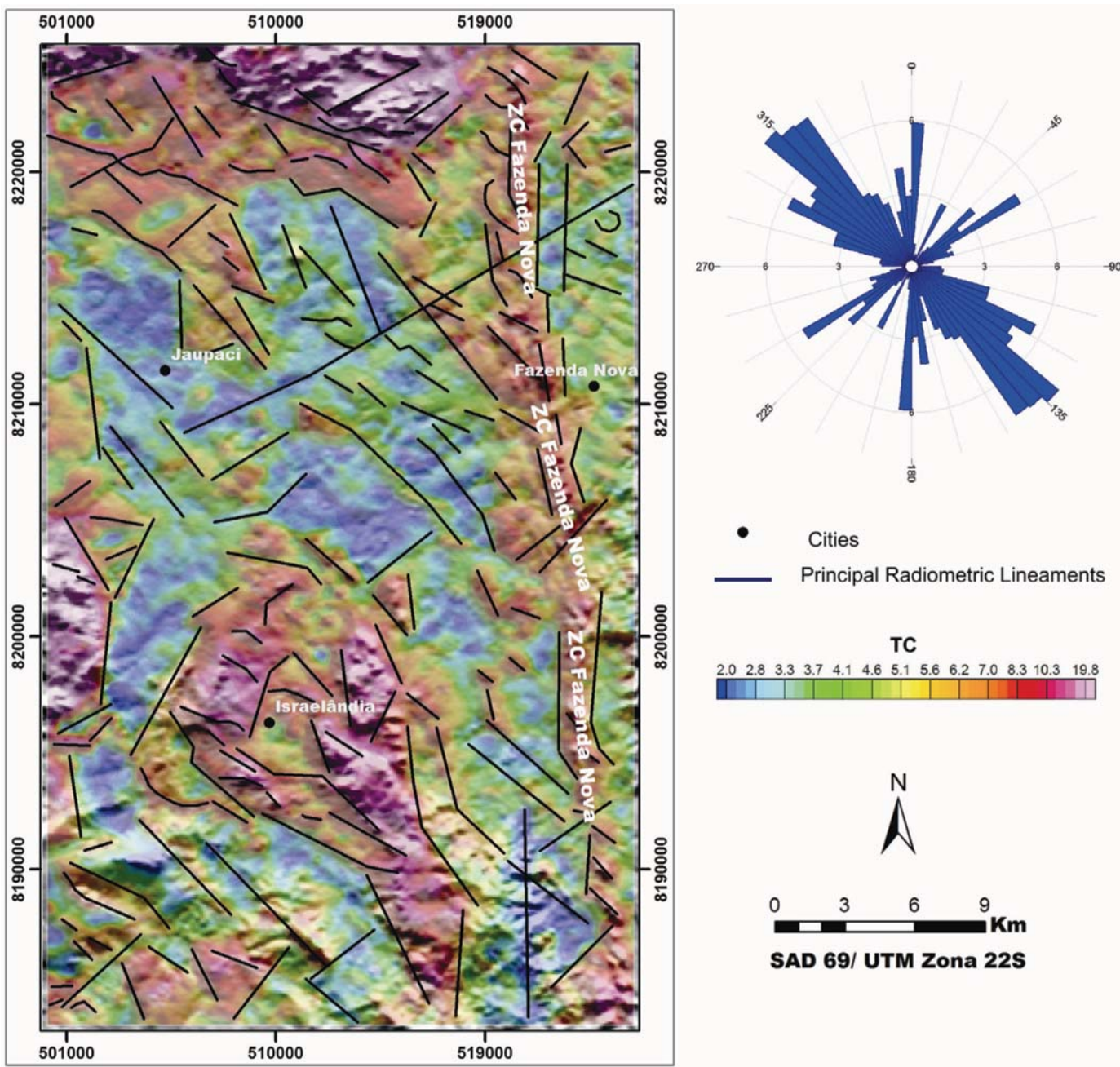

Figure 12 - Radiometric lineaments interpreted from the total count channel image with illumination in $45^{\circ}$ and $315^{\circ}$ superimposed on the total count window image and the Digital Terrain Model, originated from the SRTM image, and rosette diagram of lineaments.

The Fazenda Nova Shear Zone (FNSZ) identified in gamma spectrometric images was nonexistent in the magnetometric products since it does not present magnetic minerals. This zone provides the main NS structure with subordinate NW direction (Fig. 12). The FNSZ has dextral shear movement that generated the NW subsidiary shear systems crisscrossing the entire length of the study area. This fact indicates the existence of non-magnetic lineaments in the area, as seen in the integrated geologicalgeophysical units map (Fig. 15).

The interpreted magnetic lineaments present main EW and NW-SE trending structure and are cut by major NE lineaments, representatives of the Brasiliano Cycle, the last active tectonicmetamorphic event in the region (Fig. 13). The largest NE and NW trending structures identified are respectively associated with the first and second deformation phase, which developed folia- tion with general $\mathrm{N} 50^{\circ}-35^{\circ} \mathrm{E}$ and $\mathrm{N} 50^{\circ}-35^{\circ} \mathrm{W}$ direction (Amaro, 1989). The third deformation phase has $N 50^{\circ}-80^{\circ} \mathrm{W}$ direction (Amaro, 1989) and is associated with smaller E-W and NW-SE trending structures.

The NW-SE and NE lineaments are related to regional shear assigned to Moiporá-Novo Brasil shear system, located east of the study area, and are in agreement with the two main patterns observed regionally. The Alto Parnaíba Lineament, with NW direction, is responsible for the intrusion of Cretaceous alkaline bodies distributed according to N30W, as well as the intersections between this lineament and the faults of the general NE trending Transbrasiliano lineament, which also represent preferred sites for the intrusion of magmatic alkaline (Junqueira-Brod et al., 2002; Moura, 2007). These intrusions indicate that NE fractures are deep and were reactivated during the Cretaceous. 


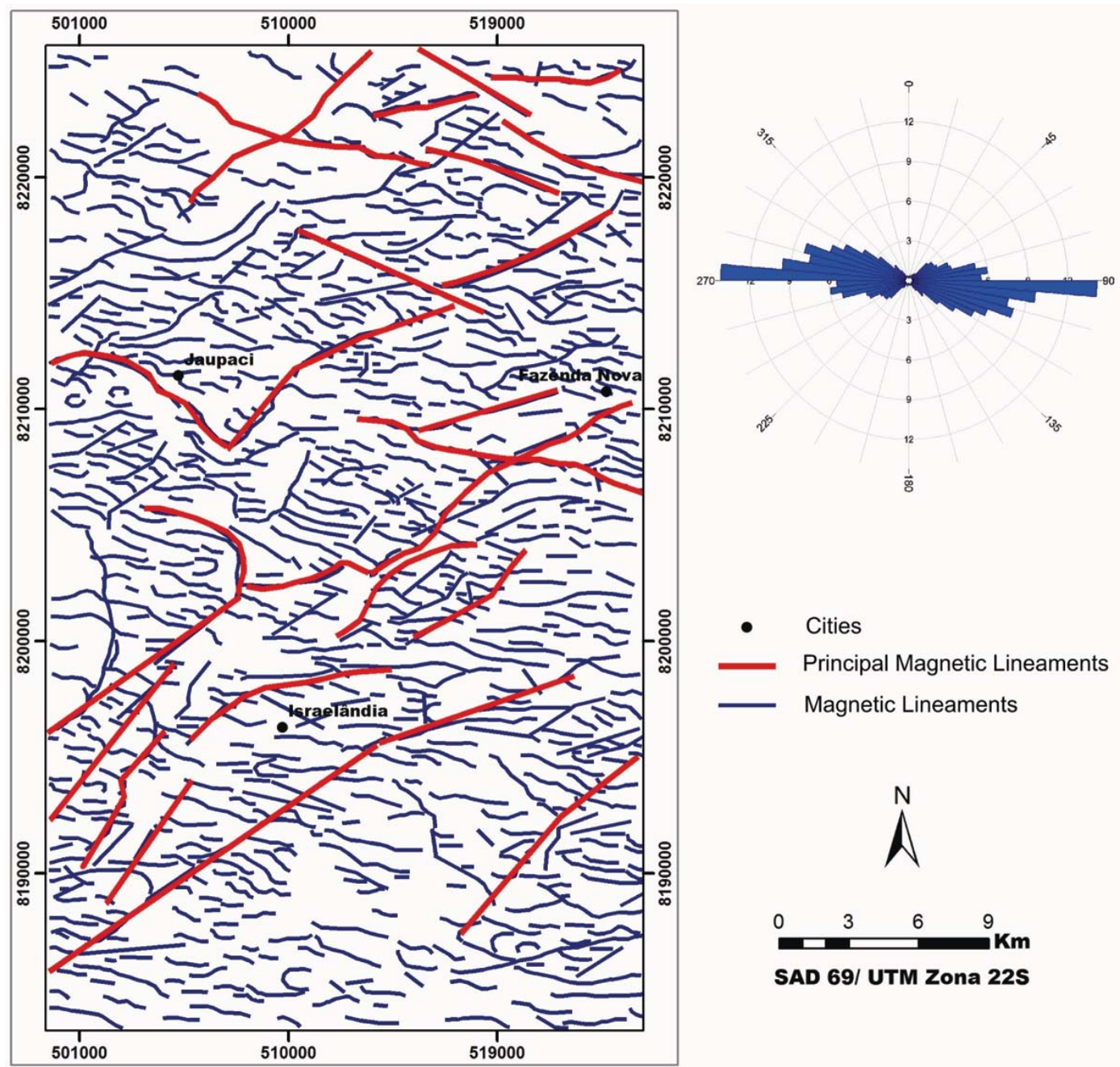

Figure 13 - Magnetic lineaments interpreted from the images derived from the anomalous magnetic field and the tilt derivative and rosette diagram of the lineaments.

The main structural feature of the Jaupaci Vulcano-Sedimentary Sequence is a vertical NS-NNW mylonitic foliation with shear kinematic indicators displaying directional dextral movements (Amaro, 1989), as observed in the magnetic lineament movements and in the sigmoidal quartz veins parallel to foliation (Fig. 14).

\section{Integrated geophysical units}

The gamma-ray spectrometric domains and geophysical lineaments interpreted from the images of gamma spectrometry and magnetometry were integrated and overlapped to the image of digital elevation models of SRTM (Fig. 15). The lithogeophysical map generated shows 15 individualized units very similar to the geological map published by Moreira et al. (2008) (Fig. 2), mainly regarding the orogenic granitic intrusions and the formations of the Paraná Basin.

The map created using the radioelement level classification resulted in individualized domains within the geological units, which may represent different rock associations and weathering processes which lead to the dispersion of radionuclides.

The gamma spectrometric images allow identifying the limits of the Furnas Formation rocks similar to those illustrated in the geological map of the region, while the main granitic intrusions were well visualized, despite different extensions in the different maps. In the area associated with the orthogneiss, different gamma radiometric signatures were identified mainly associated with the presence of shear zones, whose extensions may be inserted into a more detailed geological map of the region. 


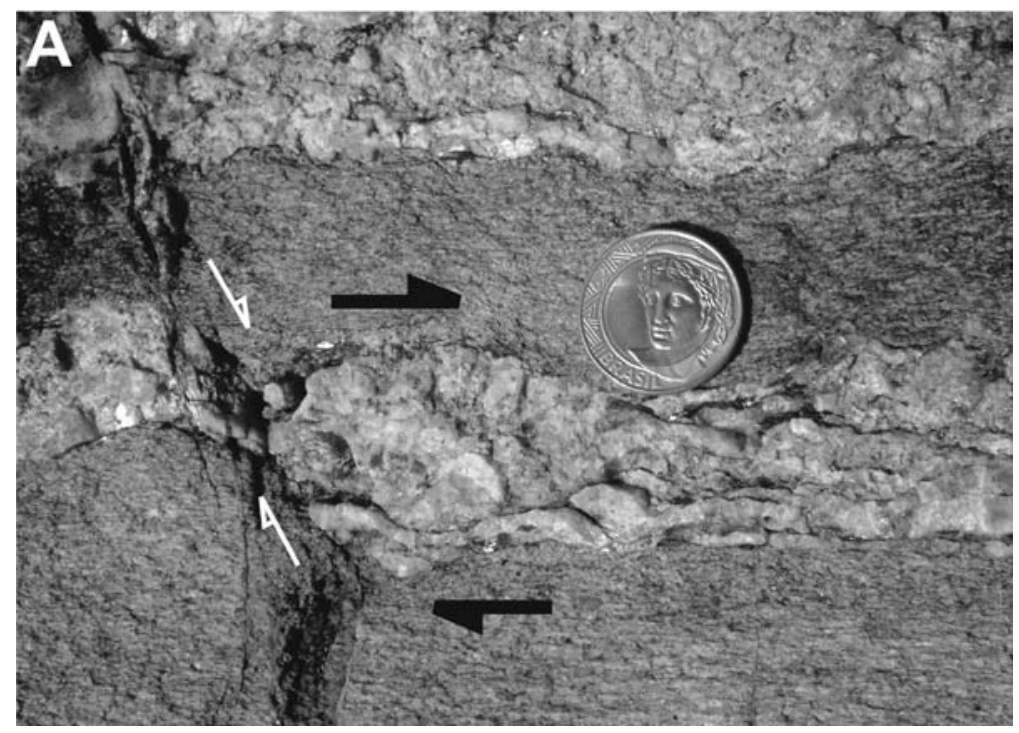

Figure 14 - Sigmoid of quartz-feldspar in schist muscovite quartz of the Fazenda Nova Shear Zone showing dextral movement.

The units of the Jaupaci Vulcano-Sedimentary Sequence were not individualized due to lacking gamma spectrometric contrast between this and adjacent units or due to advanced weathering process plus the small extension of its basic dikes, being represented by gamma-ray spectrometric domains spanning from the orthogneiss to the syn to post-orogenic granites. Domain 8 comprises the basalt dykes of the sequence of volcanic rocks, with different potassium and uranium contents. This distinct association may represent areas subjected to the hydrothermal alteration process with potassium enrichment, which contrasts the low to medium radiometric response of this unit in the gamma spectrometric images of the individual channels.

A small extension of the orogenic granite intrusion in the central-west part of the area, known as Fazenda Jaraguá Granite (Amaro, 1989), contributed to its non-individualization. The Fazenda Boqueirão Granite (Amaro, 1989) located in the eastcentral portion of the area also was not identified in the gamma spectrometric images and was targeted for contact reassessment to improve the geological mapping of the region. Domain 6, inserted in the Israelândia Granite, presents potassium leaching, which is represented in the area of influence of Rio Claro.

Domain 9 has low uranium and thorium, and medium potassium content, representing one of the different bodies identified in the alkaline province in southern Goiás, which also appears in the northwestern portion of the study area. However, this domain inserted in the alkaline province is assigned to rocks with lower potassium, while the one located in the NW portion of the area has a higher content of this radioelement. The latter is probably associated with the weathering of volcanic rocks and the consequent accumulation of potassium in the contacts between the Jaupaci volcano-sedimentary sequence and lateritic-detritic covers.

Low radiometric values represented by a circular body on the northern edge of the alkaline province may refer to rocks bearing relevant mineral deposits (Fig. 9), such as carbonatites, which could be a prospective target for finding niobium and phosphate deposits.

The lithogeophysical map also displays the intersection of NW-SE trending gamma-ray spectrometry lineaments and mainly EW and NE-SW trending magnetic lineaments. This intersection constituted preferential zones for the intrusion of alkaline bodies and can also represent preferred areas for the occurrence of gold deposits in the region.

\section{CONCLUSION}

The pre-processing and processing techniques used for the airborne geophysical data were effective to produce magnetic and gamma radiometric images of the study area. The interpretation of the generated images advanced the geological knowledge of the region, since it allowed the individualization of domains of geological units and the characterization of the local structural framework, presenting contributions to the improvement of the latest geological map of the area covered, published by Moreira et al. (2008). 


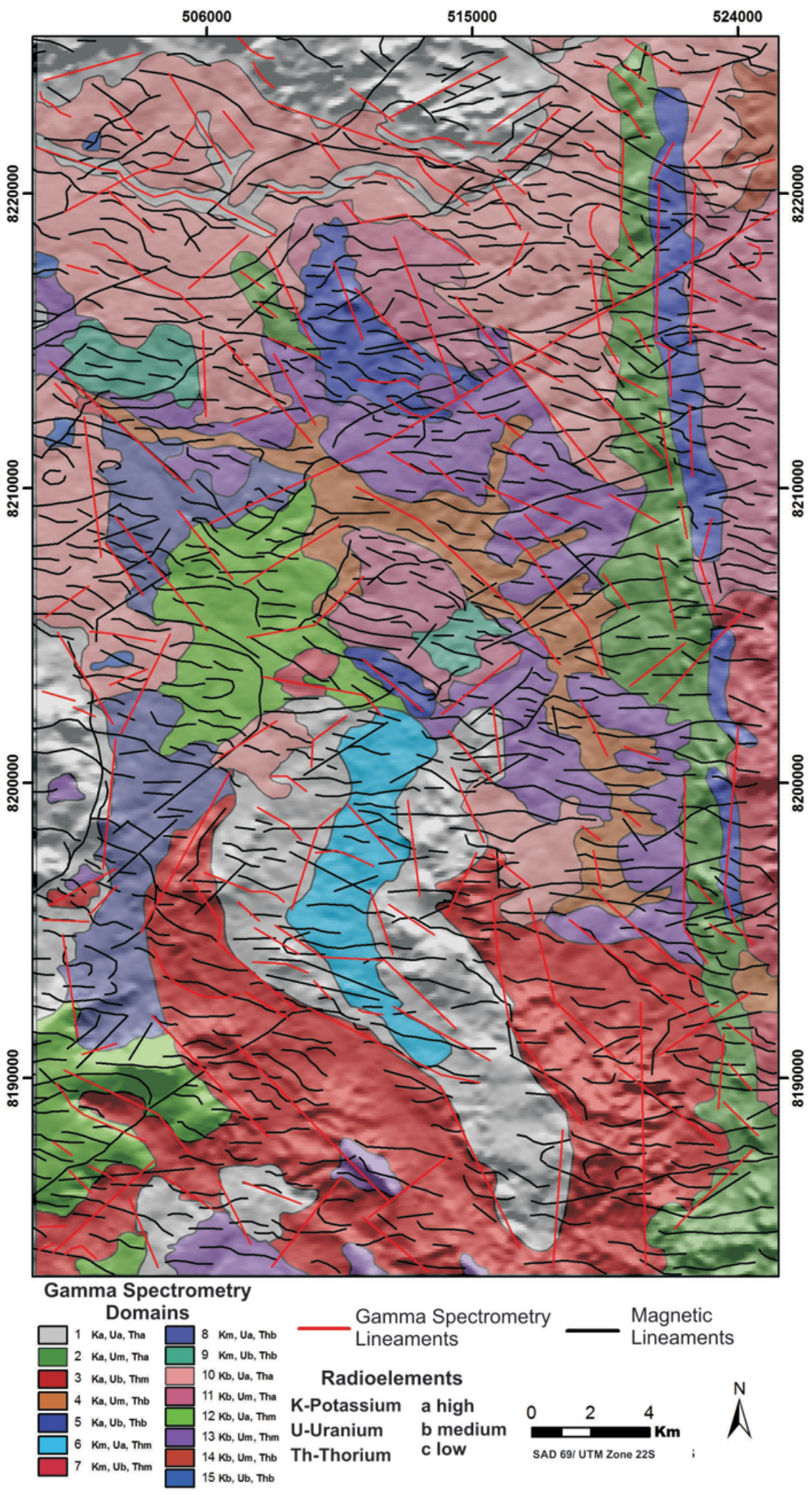

Figure 15 - Lithogeophysical map of the study area overlaid on the SRTM image. 
The orogenic granitic bodies were enhanced on all images and gamma-ray spectrometric profiles, which can aid a better delineation of this unit contacts. The gamma radiometric data also helped in identifying different rock types associated with the Iporá Alkaline Province in the central portion of the study area and the delimitation of lateritic covers, according to potassium depletion and relative thorium enrichment. The scarcity of outcrops in supracrustal units and the occurrence of large weathered areas make airborne gammaspectrometry an appropriate tool for geological mapping in the Fazenda Nova region.

The identification and delineation of the extent of major and subsidiaries shear zones present in the area allow using it in studies relating these zones of hydrothermal fluid percolation with the gold deposits and, therefore, assisting in the exploration of gold in the Fazenda Nova region.

\section{ACKNOWLEDGMENTS}

The authors thank the Serviço Geológico do Brasil (CPRM) and the Department of Trade and Industry, Superintendência de Geologia e Mineração do Estado de Goiás for releasing the airborne geophysical data, to Yamana Gold for providing the cores from the borehole of Bacilândia deposit. The first author also thanks the Coordenação de Aperfeiçoamento de Pessoal de Nível Superior (CAPES) for granting the scholarship.

\section{REFERENCES}

ALMEIDA FFM, HASUI Y, NEVES BBB \& FUCK RA. 1977. Províncias estruturais brasileiras. In: SBG, Simpósio de Geologia do Nordeste, 8., Proceedings..., p. 363-391.

AMARO VE. 1989. Geologia e petrologia da sequência metavulcânica de Jaupaci-G0 e lineamentos associados. Master Dissertation. Instituto de Geociências da Universidade de Brasília, 220 pp.

BLAKELYRJ. 1996. Potential Theory in Gravity \& Magnetic Applications. Cambridge University Press, 441 pp.

BLUM MLB. 1999. Processamento e interpretação de dados de geofísica aérea no Brasil Central e sua aplicação à geologia regional e à prospecção mineral. Doctorade Thesis. Instituto de Geociências da Universidade de Brasília, 229 pp.

GUNN PJ. 1998. Interpretation of Airborne Magnetic and Radiometric Surveys. AGSO, 150 pp.

IAEA (International Atomic Energy Agency). 2003. Guidelines for radioelement mapping using gamma-ray spectrometry data. Viena, 173 pp.

JUNQUEIRA-BROD TC, ROIG HL, GASPAR JC, BROD JA \& MENESES PR. 2002. A Província Alcalina de Goiás e a extensão do seu vulcanismo kamafugítico. Revista Brasileira de Geociências, 32(4): 559-556.
LACERDA FILHO JV, REZENDE A \& SILVA A. 2000. Geologia e recursos minerais do Estado de Goiás e Distrito Federal. Goiânia. CPRM/METAGO/UnB. Programa de Levantamentos Geológicos Básicos. 203 pp.

LAUX JH, PIMENTEL MM, DANTAS EL, ARMSTRONG R, ARMELE A \& NILSON AA. 2004. Mafic magmatism associated with the Goiás Magmatic Arc in the Anicuns-Itaberaí region, Goiás, Brazil: Sm-Nd isotopes and new ID-TIMS and SHRIMP U-Pb data. Journal of South America Earth Science, 16(7): 599-614.

LUYENDYK APJ. 1997. Processing of airborne magnetic data. AGSO Journal of Australian Geology \& Geophysics, 17(2): 31-38.

MINTY BRS. 1991. Simple Micro-Levelling for Aeromagnetic Data. Exploration Geophysics, 22: 591-592.

MINTY BRS. 1997. Fundamentals of airborne gamma-ray spectrometry. AGSO Journal of Australian Geology and Geophysics, 17(2): 39-50.

MOREIRA MLO, MORETON LC, ARAÚJO VA, LACERDA FILHO JV \& COSTA HF. 2008. Geologia do Estado do Goiás e do Distrito Federal. Escala 1:500.000. Goiânia: CPRM/SIC - FUNMINERAL, 143 pp.

MOTA-ARAÚJO JG, PIMENTEL MM \& RICHARD A. 2002. Idade e significado do sistema de cisalhamento Moiporá-Novo Brasil no Arco Magmático de Goiás: novos dados U-Pb SHIMP e Sm-Nd. In: Congresso Brasileiro de Geologia, 41., João Pessoa. Proceedings..., 486 pp.

MOURA C0. 2007. Geologia do sudeste do Estado de Goiás: integração de dados geológicos e geofísicos de alta densidade. Master Dissertation. Instituto de Geociências, Universidade de Brasília. 135 pp.

PIMENTEL MM \& FUCK RA. 1987. Late Proterozoic granitic magmatism in southwestern Goiás, Brazil. Revista Brasileira de Geociências, 17(4): 415-425.

PIMENTEL MM \& FUCK RA. 1992. Neoproterozoic crustal accretion in central Brazil. Geology, 20: 375-379.

PIMENTEL MM, FUCK RA \& BOTELHO NF. 1999. Granites and the geodynamic history of the Neoproterozoic Brasilia Belt, Central Brazil: a review. Lithos, 20: 463-483.

PIMENTEL MM, FUCK RA, JOST H, FERREIRA FILHO CF \& ARAÚJO SM. 2000. The Basement of the Brazilian Fold Belt and the Goiás Magmatic Arc. In: CORDANI UG, MILANI EJ, THOMAZ FILHO A \& CAMPOS DA (Eds.). Tectonic Evolution of South America. Rio de Janeiro: $31^{\text {st }}$ International Geological Congress, p. 195-224.

PIMENTEL MM, HARD J \& FUCK RA. 2004. 0 Embasamento da Faixa Brasília e o Arco Magmático. In: MANTESSSO-NETO V, BARTORELI A, DAL RÉ CARNEIRO C \& BRITO-NEVES BB (Organizadores). Geologia do Continente Sul Americano: Evolução da Obra de Fernando Marques de Almeida. São Paulo. Ed. Beca. Cap. 21, p. 335-368.

RODRIGUES JB, GIOIA SMLC \& PIMENTEL MM. 1999. Geocronologia e geoquímica de rochas ortognáissicas da região entre Iporá e 
Firminópolis: implicações para a evolução do Arco Magmático de Goiás. Revista Brasileira de Geociências, 29(2): 207-216.

VASCONCELOS RM, METELO JM, MOTA CA \& GOMES DR. 1994. Geofísica em levantamentos geológicos no Brasil. Rio de Janeiro. CPRM. 172 pp.

Recebido em 11 junho, 2012 / Aceito em 10 setembro, 2013

Received on June 11, 2012 / Accepted on September 10, 2013
WILFORD JR, BIERWITH PN \& CRAIG MA. 1997. Application of airborne gamma-ray spectrometry in soil/regolith mapping and applied geomorphology. AGSO Journal of Australian Geology and Geophysics, 17(2): 201-2016.

\section{NOTES ABOUT THE AUTHORS}

Lara Nigro Rodrigues Alves Ramos. Holds degree in Geology (2005) and M.Sc. in Economic Geology and Prospecting (2010) from the Universidade de Brasília, with focus on geophysics applied to mineral prospecting. Is specialized in Geoprocessing (2008) and has experience in mineral exploration of base metals in the Amazon region. Works mainly in the area of Applied Geophysics with data processing and integration applied to geological mapping and mineral exploration.

Augusto César Bittencourt Pires. Geologist graduated in 1968 from the UFRJ. Holds a Ph.D. in Geophysics from Colorado School of Mines, in 1975. Head of the Department of Geophysics of ENCAL SA; Head of the Department of Geophysics of the Observatório Nacional. In CNPq, worked as Supervisor, Coordinator and Superintendent of Ciências Exatas e da Terra and Director. Was Program Director of CAPES and Policy and Plans Coordinator of MCT. Was gazetted Senate Legislative Consultant. Specialized in the application of geophysical methods in geological mapping, mineral exploration and environmental analysis. Retired Professor of the Geosciences Institute and, currently, Senior Researcher, at UNB.

Catarina Labouré Benfica Toledo. Geologist graduated from Universidade Federal do Rio de Janeiro in 1990. Holds a Master in Metalogenesis (1997) and a Ph.D. in Geosciences (2002) from the Universidade Estadual de Campinas. Post-doctorate (2006) from the Universidade Estadual Paulista researching the Crustal Evolution of Pre-Cambrian terrains. Currently, is a Professor at the Universidade de Brasília (2007), working mainly in the igneous and metamorphic petrology field, geological mapping and crustal evolution in Archean terrains. 